\title{
Model of Educational Work on Career Guidance in the System of Secondary Vocational Education
}

\section{Modelo de Trabajo Educativo en Orientación Profesional en el Sistema de Educación Secundaria Profesional}

\author{
Olga Nikolaevna Goncharenko \\ State Agrarian University of the Northern Trans-Urals, Tyumen, Russian Federation \\ https://orcid.org/0000-0003-3459-5623 \\ Svetlana Nikolaevna Semenkova \\ State Agrarian University of the Northern Trans-Urals, Tyumen, Russian Federation \\ https://orcid.org/0000-0003-0152-1070
}

*Correspondencia

Email: goncharenko-65@mail.ru 


\section{Summary}

Youth is a dynamically developing social group that actively participates in the reproduction process of the social and professional structure of society. The complication of production processes and rapid scientific and technological progress increase the importance of this social group in Russian society. This scientific article attempts to study the level of implementation of career guidance in the system of educational work of an educational institution of secondary professional level. Using a system-synergetic approach and various methods of scientific research, the authors revealed not only the state of the problem under consideration but also determined the relevance of such research in contemporary conditions. Based on the obtained data, a theoretical universal model of educational work has been developed, which assumes the formation of value orientations among young people in the course of its implementation. The student professional development model concerning the educational activities of the College consists of three interrelated units: target, substantive-operational, and evaluation- performance blocks. The model provides self-development of the individual through the cardinal renewal of all the above-mentioned components, and the formation of general cultural competencies. The main advantage of the created model is the development of complete professionalism through the implementation of career growth mechanisms in students, as well as the orientation of young people to actively search for innovative conditions for professional self-actualization and civicmindedness.

Keywords: Professional Self-Determination, System-Synergetic Approach, Career Guidance, Secondary Vocational Education.

\section{Resumen}

La juventud es un grupo social en desarrollo dinámico que participa activamente en el proceso de reproducción de la estructura social y profesional de la sociedad. La complicación de los procesos de producción y el rápido progreso científico y tecnológico aumentan la importancia de este grupo social en la sociedad rusa. Este artículo científico intenta estudiar el nivel de implementación de la orientación profesional en el sistema de trabajo educativo de una institución educativa de nivel profesional secundario. Utilizando un enfoque sinérgico de sistemas y varios métodos de investigación científica, los autores revelaron no solo el estado del problema en consideración, sino que también determinaron la relevancia de dicha investigación en las condiciones contemporáneas. A partir de los datos obtenidos se ha desarrollado un modelo teórico universal de trabajo educativo, que asume la formación de orientaciones valorativas entre los jóvenes en el transcurso de su implementación. El modelo de desarrollo profesional estudiantil relativo a las actividades educativas del Colegio consta de tres unidades interrelacionadas: bloques objetivo, sustantivo-operativo y evaluación-desempeño. El modelo proporciona el autodesarrollo del individuo a través de la renovación cardinal de todos los componentes antes mencionados y la formación de competencias culturales generales. La principal ventaja del modelo creado es el desarrollo de una completa profesionalidad a través de la implementación de mecanismos de crecimiento profesional en los estudiantes, así como la orientación de los jóvenes a la búsqueda activa de condiciones innovadoras para la autorrealización profesional y la mentalidad cívica.

Palabras clave: Autodeterminación profesional, Enfoque sinérgico del sistema, Orientación profesional, Educación vocacional secundaria.

\section{Introducción}

Contemporary socio-economic conditions have significantly changed the approach to the professional education and professional self-determination of young people (Semenkova, 2016). The contemporary system of domestic education orients the younger generation to actively search for innovative conditions for professional self-actualization. Young people are 
waiting for answers to questions: "What professions will be in demand in the future?", "Do the chosen specialties meet the constantly changing socio-economic conditions?" Increased competition in the labor market has heightened the public need to solve the problem of the career guidance of young people and caused the need for motivational structuring of the educational work process in this area. Today, more than ever, it is important to create an order for the quality of professional education not only and not so much in the knowledge format of graduates, but in the ability to extract, process, and apply knowledge in specific standard and nonstandard conditions based on a certain bundle of knowledge and background. The development of the ability to work constructively in a market economy implies the development of professional universalism, readiness to learn new types of activities, while integration into the world community means the preparedness for cooperation, dialogue, understanding of other views, and a different professional culture (Semenkova, 2016).

Besides, the market economy not only creates conditions for free action of each person but also imposes high requirements on him, namely, the ability to choose independently, to be prepared for unpredictable situations and risks associated with economic behavior. Professional self-determination is directly related to the civil position since there is a contradiction between the objectively existing needs of society in a balanced structure of personnel and the inadequately formed subjective professional aspirations of young people (Semenkova, 2015; Semenkova et al., 2018). When eliminating this contradiction, it is important to correctly form a civic-mindedness, which consists in explaining the need to form certain professional groups.

Thus, the solution to the problem of preparing a person for conscious professional selfdetermination, the formation of economic stability, and civic-mindedness becomes vital. The "Concept of long-term socio-economic development of the Russian Federation until 2020" states that the level of competitiveness of the contemporary innovative economy is largely determined by the quality of professional personnel, their level of socialization and cooperation. The famous Russian sociologist V.N. Shubkin (2010) emphasized: "Only very naive people can hope that the problems of self-determination [of young people] can be solved by psychotechnicians or economists because not everyone understands their complexity and depth". Therefore, transferring the formation of professionalism to the field of educational work becomes important and necessary. The purpose of the present article is to analyze the current status of career guidance in extracurricular time and create a universal model of educational work related to career guidance and the formation of value orientations among students.

\section{Methods}

The Tyumen college of construction industry and urban economy (hereinafter College) was selected as a research object as a typical contemporary secondary vocational education institution.

The research subject was the formation mechanisms of professionalism during extracurricular time among secondary vocational education students.

A research methodology included a system-synergetic approach which allowed determining the dialectical nature and revealing the main contradiction between training and education, its structure and role in educational and extracurricular processes, as well as creating a model of career guidance in extracurricular time, which could be applied to the educational process management.

In the context of the stated approach, the study was divided into two stages: the first stage involved the collection and processing of empirical data to identify contradictions related to career guidance and educational work, while the second stage concerned creation of a theoretical model of career guidance in the educational system of secondary vocational education. To perform the tasks of the first stage, the following methods were used: the 
sociological survey in the form of a questionnaire, off-line observation, SWORD analysis, content analysis of the legal framework and reports of structural divisions of the College for the period of 2015-2019, as well as comparative and logical methods. To resolve the contradictions found at the first, empirical stage of the research, the simulation approach was used, as well as the analysis of philosophical, scientific, methodological, psychological, and pedagogical literature.

\section{Results}

Since a system-synergetic approach has been chosen to study the career guidance in extracurricular work, it should be noted that pedagogy has come much earlier than other sciences to understand the synergy in the interaction of teachers and students, and has built its qualitative picture. These achievements are reflected in the works of V.G. Vinenko, V.I. Zagvyazinsky, V.A. Ignatova, V.A. Fedorov, and other major Russian scientists (Arshinov, 1999; Vinenko, 1997; Zagvyazinsky, 1995; Zagvyazinsky, Atakhanov, 2001; Ignatova, 2001; Fedorov et al., 2008). The validity of this approach is confirmed by numerous developments in the methodology, theory, and practice of pedagogical research, including empirical material describing the educational process regularities, the conditions and factors affecting its dynamics, their relationship, the nature and depth of its contradictions, and ways to resolve them (Astafiev, Shubkin, 1996; Zakharov, Simonenko, 1989; Konstantinovsky, Shubkin, 1977; Pryazhnikov, 2008; Shamuratova, 2017). These issues are reflected also by foreign authors: H. Maturana, G. Pask, F. Varela, etc. (Maturana, 1996; Maturana, Varela, 2001).

The works of E.I. Golovakha, D.L. Konstantinovsky, A.B. Kurlov, M.Kh. Titma, and V.N. Shubkin appeal to the category of professional self-determination. These authors studied problems related to the social conditionality of the choice of certain professions, the dynamics of their prestige, and the professional interests and intentions of the youth (Golovakha, 1989; Kurlov, 1994).

Synergetic understanding of the world picture is important for human education since the synergetic way of thinking is characterized by openness, dialogic character, and communication. Synergetics orients the teacher, as the pedagogical process actor, to study the most complex internal laws of human life (Kodzhaspirova, 2004). Nikitina E.K. claims that synergetics allows restoring the connections with practical reality lost in the development of pedagogical theory, creating a communicative bridge between different components of the educational system and its subjects based on the development of dialogics, openness, and interaction. A synergistic approach to building an educational system contributes to a significant increase in its creative potential (Nikitina, 2006). Kovalevich M.S. emphasizes that synergy allows reinforcing methodologically the importance of the process of self-determination and personality development as an actor, giving a finished look to the following pedagogical categories: the educational process core is focused on a self-determining personality, while the subject of training and education is a student holding an active-creative position in the educational process with the obligatory freedom of expression and self-actualization in the educational environment, the search for individual strategies of self-determination in life and profession, as well as actualization of the principles of activity, dialogics, independence, initiative, and creativity. At that, the teacher and the student are open, self-regulating systems that seek to develop personal agency and subjectiveness, freedom to choose the strategy of an individual life path, and therefore, the choice of educational programs, courses, as well as the depth of their content, and the very teacher (Kovalevich, n.d.). According to S.D. Yakushev (2012), pedagogical science implementing the synergetic principle in education and training of a self-developing personality, implements the anthropological approach and humanistic ideas, harmoniously balancing the humanitarian and natural science worldview.

Summarizing the accumulated theoretical material, it can be stated that the systemsynergetic approach in the education allows individuals to express themselves and self-actualize in the professional and educational environment, to develop an individual strategy of professional self-determination by making use of pedagogical support. At that, professional 
development, according to the authors, is not only a process of natural change of personality, characterized by the quantitative, qualitative, and structural transformation that ensures the normal functioning of a person as a professional actor but also the process of becoming a specialist as a carrier of various types of professional activity. Professional self-determination can be implemented in several ways: first, through the student's educational activities; second through educational career guidance; third - through self-education and self-actualization in the profession, including that achieved through creative and intellectual activities (Goncharenko, Semenkova, 2017); fourth - acting as a secondary agent of children's socialization, such as a tutor telling pupils about the profession and its advantages (Goncharenko, 2014). At that, the second, third, and fourth ways are exactly educational career guidance activities, carried out mainly by indirect methods.

Thus, due to the system-synergetic approach, the educational career guidance activities will not only provide interaction between the teacher and student aimed at professional development and change in the student as a subject of education, taking into account the age characteristics, specifics of future professional activity, and peculiarities of the secondary vocational education training but also will give the student the opportunity for active learning of social experience related to the job, i.e. tutoring, creating a professional intelligent product, and taking part at professional competitions. The ways of educational career guidance outlined in this article will contribute to the professionalism of students that is very important in the modern world. According to Russian scientists, professionalism is the ability to perform specific paid functional duties, acquired in the course of training and practical activities, the level of skill and creativity in a particular occupation, which corresponds to the level of complexity of the tasks performed (Slastenin et al., 2000).

For the previous study years, considerable resources have been accumulated in the College, which include modern educational-laboratory base, highly qualified personnel, software, and educational services. An efficient system of social interaction with employers and other strategic partners (regional and urban administration, employment agency) was created that helped the College to reach a new level of solving professional education issues. Vocational guidance with students is facilitated by structural divisions of the College, such as the museum, library, sections, and circles, as well as Studen student press center, the student council, and the Svyazka volunteer team. At the same time, the disunity of individual structural divisions of the educational institution caused the emergence of problems related to professional education (Goncharenko et al., 2018).

To determine how the choice of training guidance is made, whether minds of young people are guided by professional strategies, and what they would like to get as part of professional education in an educational institution, the authors surveyed first-year students (n94) and graduate students (n-97) in September of 2018. In total, 191 people took part in the survey. The sample consisted of students majoring in the construction industry (53\%), as well as urban and municipal services (47\%). Among them, $46 \%$ of students were girls, and 54\% were boys. The survey has shown that $82 \%$ of graduated students would have liked to get acquainted with successful models of economic behavior (successful people in the profession, experience in organization of building and municipal business), $41.4 \%$ of the respondents would have liked to participate in competitions, contests, and other events expanding idea about the selected profession or related professions; $68 \%$ - to know about the prospects of learning in specialized higher education institutions; $87.3 \%$ - to know about risk factors in contemporary society and ways of overcoming them. At that, $100 \%$ of students wished to adapt to the profession while studying at the College.

The survey (questionnaire survey method) of the $1^{\text {st }}$-year students enrolled since September 1, 2018, revealed the main approaches of young people to the chosen professions. After analyzing the data from the questionnaires, one can say with confidence that the main reasons for choosing the professions offered by the educational institution, according to the respondents' answers, have been the following circumstances: the urgent need for people having such a profession (35.2\%); this profession is interesting (29.3\%); people of this profession bring 
great benefit to society (21\%), this profession is easy to learn (9\%). The other options either did not attract the attention of respondents at all (I have a good idea about the work content; my friends consider this profession very good; I know most of all about this profession; this profession allows benefitting people; there is a lot of writing and talk about this profession; mastering this profession will give me a wide outlook and culture; I will be able to achieve more in life with this profession than my parents; I have abilities for this profession), or were isolated and made up only $0.5 \%$ (the work is not very difficult; I know the work conditions well, and I like them; people of this profession enjoy special respect in society). Thus, the results of the survey revealed a lack of professional approach and economic component in the respondents' views. The majority of young people have chosen a profession based on life circumstances (48\%), on the advice of parents (28\%), depending on their abilities (12\%), or the advice of friends $(12 \%)$. At that, $62 \%$ of those who have chosen on the advice of their parents consider mastering of this profession as a step to getting a higher education. The survey also revealed problems in determining the main professional qualities of future specialists. Thus, answering the open question of the questionnaire "What are the character qualities necessary to succeed in your chosen profession?», respondents studying in "Service of household and communal services" called responsibility (62\%), while students who majored in "Installation and adjustment of electrical equipment" noted courage (32\%).

Further, 56\% of all respondents believe that the education they receive within the educational institution is sufficient for further career development. However, 59\% of respondents, out of the remaining $44 \%$, expressed certain doubts concerning the chosen specialty, and the need for assistance from professionals and teachers regarding personal professional development. At that, $100 \%$ of the respondents believe that while one is studying, he must acquire experience through production and technological practice. First-year students (59\%) believe that if they were again in a situation of choice, they would not choose this specialty as a professional activity. The respondents' opinions indicate that their professional views are mostly quite narrow, they poorly perceive their life professional path, and, accordingly, their professional choice made based on life circumstances, the advice of parents or friends can and should be influenced through training activities and, to a greater extent, through upbringing work. This work will create in a mild indirect form the conditions for attachment in the minds of the students the correct initial choice of profession, especially because of the results of a survey of $4^{\text {th }}$ last course students (n-97) which showed that $67.3 \%$ of respondents were interested in studying at the College, while $21.6 \%$ were more likely to be interested than not, and only $11.1 \%$ had a negative rather than positive attitude to study. Answers to the question "If you had the opportunity, would you change educational and (or) professional choice", have shown that $54.5 \%$ of students would change nothing; $44.3 \%$ believe that studying in College, they were strengthened in the correctness of the made choice, even though when entering the College, they dreamed to change their specialty in the future (64\%). At that, $61.8 \%$ of respondents need to acquire additional knowledge related to economic risks in the profession, adaptation in a society with a market economy, systematic training in entrepreneurship, and building a career path.

When studying training and education plans of the College, activities of the museum, and the student society in 2017-2019, it was revealed that career guidance was carried out in the framework of the educational process, including through master classes, internships of students at enterprises, interviews with graduates, the involvement of business representatives in the events of the College, as well as technical tours to enterprises. Students are intending to participate in professional skills competitions, contests, festivals, and conferences of various levels. Masters of vocational training prepare worthy College representatives for these events. College students have won numerous national and international competitions, including the well-known WorldSkills Competition. Nevertheless, the work plans of the main agents of vocational education, i.e. curators, educational organizers, educational psychologist, library, student council, mainly consist of civil-patriotic and creative efforts, diagnostics of individual inclinations and group cohesion of the student group, adaptation in society rather than in the profession. Thus, out of the 32 conducted activities, three events were related indirectly to career guidance: "Law, and us"," These are my rights, and what about duties?", and "Economics 
lessons" $(10.1 \%)$. A similar picture is observed in the work plan of the student council, as well as the education organizer. Only in the library activities (15 events out of 31 were dealt with professional education), as well as student groups and sections (out of 22 sections and groups, 11 were aimed at expanding knowledge and skills in the profession, and the mastery of related specialties) career education and guidance were carried out adequately.

Thus, the activities carried out at the College were not fully aimed at the career guidance of students and required the creation of an educational work model related to the vocational guidance of students. The model developed by the authors is based on the following aspects which concern an individual's self-determination and development as a coordinator of an activity.

1. The economic behavior aspect: familiarization of students with successful models of economic behavior in construction and utilities (successful people in the profession, College graduates, experience in organizing construction and utility business, economic and social risks);

2. The individuality aspect implemented in the construction of an individual professional career trajectory involving portfolio, psychological and pedagogical assistance in professional self-determination, and the professional career map;

3. The aspect of creative, cognitive, and research potential necessary for the future profession: competitions, research projects, contests, exhibitions, and conferences;

4. The aspect of readiness for professional self-actualization: volunteer teams to assist socially vulnerable categories of the population, using the received professional experience; volunteer teams of tutors for schoolchildren;

5. The aspect of adaptation for social and professional activities, involving conversations, lectures, meetings, competitions, including environmental, health-saving, labor protection, psychological and pedagogical assistance;

6. The aspect of responsibility to the chosen profession, and specialty, involving professional skills competitions, subject contests, participation in the volunteer movement, and the coverage of the media and social network activities.

The above aspects all together will ensure systematic work that will lead to the formation of a responsible professional. Thus, the professional development model of students in educational activities of the College consists of three interrelated blocks: target block, which includes the goal and objectives for the development of the social activity of students; contentoperational block, reflecting the main directions of educational activities, forms, and methods of teachers' work with students and parents; as well as evaluative and effective block, which includes the criteria and levels of competencies formation resulting from professional development of secondary vocational education students (Table 1).

Table (1): The model of educational work in vocational guidance in the secondary vocational education system

\begin{tabular}{|c|c|c|c|c|c|c|}
\hline$\frac{\frac{1}{8}}{\frac{1}{2}}$ & \multicolumn{6}{|c|}{$\begin{array}{l}\text { DEVELOPMENT OF PROFESSIONALISM THROUGH THE IMPLEMENTATION OF } \\
\text { CAREER GROWTH MECHANISMS IN SECONDARY VOCATIONAL EDUCATION STUDENTS }\end{array}$} \\
\hline 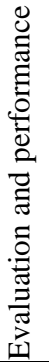 & $\begin{array}{l}\text { Getting to } \\
\text { know } \\
\text { successful } \\
\text { people and } \\
\text { economic } \\
\text { behavior } \\
\text { models }\end{array}$ & $\begin{array}{l}\text { Building an } \\
\text { individual } \\
\text { professional } \\
\text { career trajectory } \\
\text { (portfolio, } \\
\text { psychological } \\
\text { and pedagogical } \\
\text { assistance in } \\
\text { professional self- } \\
\text { determination, }\end{array}$ & $\begin{array}{l}\text { Participation } \\
\text { in } \\
\text { competitions, } \\
\text { student } \\
\text { scientific } \\
\text { research } \\
\text { projects, } \\
\text { contests, } \\
\text { exhibitions, } \\
\text { and }\end{array}$ & $\begin{array}{l}\text { Participation in } \\
\text { volunteer teams } \\
\text { to assist socially } \\
\text { vulnerable } \\
\text { categories of the } \\
\text { population using } \\
\text { the received } \\
\text { professional } \\
\text { experience; } \\
\text { participation of }\end{array}$ & $\begin{array}{l}\text { Organization } \\
\text { and } \\
\text { participation in } \\
\text { conversations, } \\
\text { lectures, } \\
\text { meetings, } \\
\text { competitions, } \\
\text { including } \\
\text { environmental, } \\
\text { health-saving, }\end{array}$ & $\begin{array}{l}\text { Participation in } \\
\text { professional } \\
\text { skills } \\
\text { competitions, } \\
\text { subject } \\
\text { contests, the } \\
\text { volunteer } \\
\text { movement, } \\
\text { coverage of } \\
\text { mass media }\end{array}$ \\
\hline
\end{tabular}




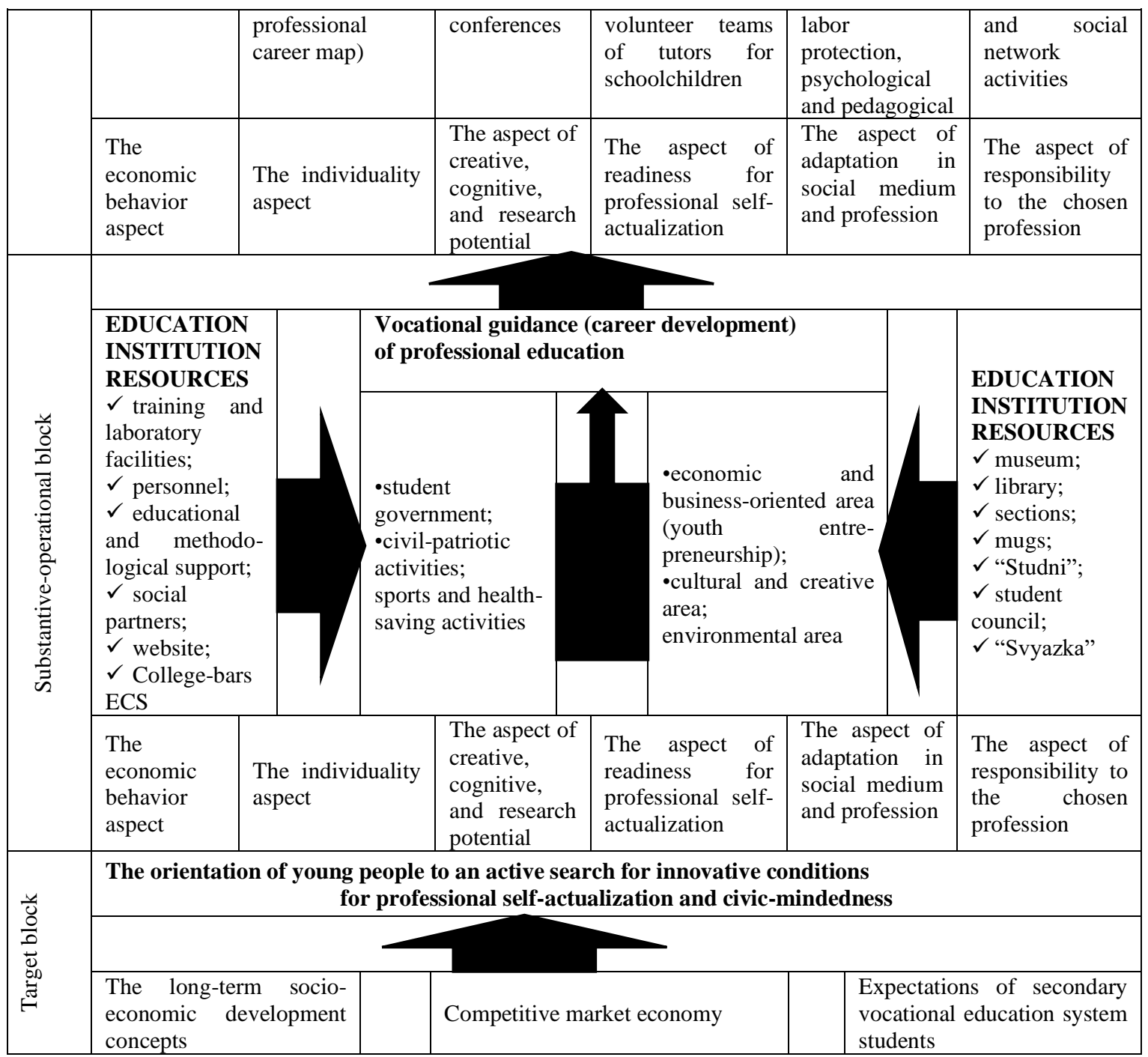

According to the authors, the proposed model will ensure the self-development of the individual through the cardinal renewal of all the above-mentioned components and will form not only professional but also general cultural competencies.

\section{Conclusions}

The analysis of the research materials allows drawing several conclusions:

1. The authors revealed not only the state of the problem under study but also the relevance of such research for contemporary conditions, as well as the proposed pedagogical approach to its solution.

A system-synergetic approach is important for studying the issue of career guidance, not only concerning scientific research but also concerning the educational process. The application of this approach in the study of pedagogical problems allows detecting their dialectical nature and revealing the main contradictions of the learning and education processes, their structure and role in the educational and extracurricular processes, as well as creating a model of career guidance during the extracurricular time, which can be applied to the educational process management.

The system-synergetic approach as a pedagogical method in the education allows individual to express himself and self-actualize in the professional educational environment, to 
develop an individual strategy of professional self-determination using pedagogical support. At that, professional development represents both the process of natural changes in personality, characterized by the quantitative, qualitative, and structural transformation that ensures the normal functioning of a human as a professional actor and the process of mastering various types of professional activities by the specialist. The educational activity is one of the ways to interact between the teacher and the student, aimed at mastering actively the social experience by the student, professional development and change of the student as an education actor, taking into account age characteristics, the specifics of future professional activity, and the training conditions in secondary vocational education.

2. In the course of study, a model of professional formation of the secondary vocational education students has been developed, which is defined as a generalized, abstract logical image of the specific phenomenon of the educational system that reflects and represents significant structural-functional relationships of the pedagogical research object, presented in a visual form required, and giving new knowledge about the simulation object.

According to the authors, further research should be aimed at improving the content and methods of students' professional development in the educational activities of secondary vocational schools, as well as the implementation of this model in the structure of the educational work of secondary vocational schools.

\section{Referencias}

Arshinov, V.I. (1999). Sinergetika kak fenomen postneklassicheskoj nauki [Synergetics as a phenomenon of post-nonclassical science]. Moscow: Institute of Philosophy of the Russian Academy of Sciences.

Astafiev, Ya.U., Shubkin, V.N. (1996). Sociologiya obrazovaniya v SSSR i Rossii [Sociology of education in the USSR and Russia]. World of Russia, 5(3): 161-178.

Fedorov, V.A., Gapontseva, M.G., Gapontsev, V.A. (2008). Sinergetika v pedagogike: celesoobraznost' perenosa [Synergetics in pedagogy: The feasibility of transfer]. Education and Science. Bulletin of the Ural Branch of RAS, 9(57): 100-110.

Golovakha, E.I. (1989). ZHiznennaya perspektiva i professional'noe samoopredelenie molodezhi [Life prospect and professional self-determination of youth]: Higher Doctorate thesis in philosophy: 09.00.09. Academy of Sciences of the Ukrainian SSR. Kyiv: Institute of Philosophy.

Goncharenko, O.N. (2014). "Faktory, vliyayushchie na formirovanie cennostej sel'skoj molodezhi [Factors influencing the formation of values of rural youth]". In: O.N. Goncharenko, L.I. Yakobyuk (eds.), Proceedings of the International science-topractice conference "Issues of forming value orientations in the education of rural youth", Tyumen, Russia, June 5-6, 2014. Tyumen': GAU Severnogo Zaural'ya.

Goncharenko, O.N., Krasnolobova, E.P., Cheremenina, N.A., Sidorova, K.A., Veremeeva, S.A. (2018). Case-method in the structure of training the veterinary physician. Astra Salvensis, 6: 647-655.

Goncharenko, O.N., Semenkova, S.N. (2017). Opyt formirovaniya agrarnogo soznaniya u sel'skih detej i molodezhi $\mathrm{v}$ agrarnom vuze [Experience of forming agrarian consciousness in rural children and youth in an agricultural university]. Scientific Review: Humanities Research, 7: 89-98.

Ignatova, V.A. (2001). Pedagogicheskie aspekty sinergetiki [Pedagogical aspects of synergetics]. Pedagogy, 8: 26-31.

Kodzhaspirova, G.M. (2004). Pedagogika: uchebnik [Pedagogy: textbook]. Moscow: Gardariki.

Konstantinovsky, D.L., Shubkin, V.N. (1977). Molodezh' i obrazovanie: metodicheskie voprosy $\mathrm{i}$ opyt social'nogo prognozirovaniya na materialah sociologicheskih obsledovanij v Novosibirskoj oblasti [Youth and education: Methodological issues and experience of social forecasting based on the sociological surveys in the Novosibirsk Region]. Moscow: Nauka. 
Kovalevich, M.S. (n.d). Social'no-psihologicheskie i pedagogicheskie problemy professionalizacii lichnosti: sinergeticheskij podhod [Socio-psychological and pedagogical problems of professionalization of the individual: a synergetic approach]. International internet conference. Retrieved from: https://sites.google.com/site/konfep/Home/2-sekcia/kovalevic

Kurlov, A.B. (1994). Effektivnost' i kachestvo inzhenernoj podgotovki kak social'naya problema [Efficiency and quality of engineering training as a social problem]: Higher Doctorate thesis in social sciences. Ufa: Bashkir State University.

Maturana, H.R. (1996). Biology of Cognition. Language and intelligence. Trans. from English by Yu.M. Meshenin. Moscow: Izdatel'skaya gruppa "Progress".

Maturana, H.R.., Varela, F.J. (2001). Drevo poznaniya: biologicheskiye korni chelovecheskogo ponimaniya [The Tree of Knowledge: The Biological Roots of Human Understanding]. Trans. from English by Yu.A. Danilov. Moscow: ProgressTraditsiia Publ.

Nikitina, E.K. (2006). "Upravlenie kachestvom vospitaniya v sisteme podgotovki sovremennogo specialista [Education quality management in the system of training of a modern specialist]". In: A.G. Kutuzov, E.G. Chernysheva (eds.), Scientific notes of the Moscow Humanitarian Pedagogical Institute. Vol. 4, pp. 200-211. Moscow: MGPI.

Pryazhnikov, N.S. (2008). Professional'noe samoopredelenie: teoriya i praktika [Professional self-determination: Theory and practice]. Moscow: Academy Publishing Center.

Semenkova, S.N. (2015). Vliyanie moral'no-nravstvennyh kachestv na professional'noe stanovlenie cheloveka [Influence of moral qualities on the professional development of a person]. Agro-Food Policy of Russia, 3: 73-75.

Semenkova, S.N. (2016). Uchet psihologo-pedagogicheskih osobennostej podrastayushchego pokoleniya pri realizacii proforientacionnoj deyatel'nosti $\mathrm{v}$ proekte "Agrocivilizaciya" [Considering psychological and pedagogical features of the younger generation in the implementation of career guidance in the frameworks of Agrocivilization project]. Agro-Food Policy of Russia, 5: 14-17.

Semenkova, S.N., Bannykh, S.G., Doronina, M.V. (2018). System grounds of social management theory. RPTSS 2017 International Conference on Research Paradigsm Transformation in Social Sciences. The European Proceedings of Social and Behavioural Sciences(EpSBS), 138: 1173-1179.

Shamuratova, G.Yu. (2017). Sinergeticheskij podhod kak forma mnogovariantnosti v obrazovatel'nom processe [Synergetic approach as a form of multivariance in the educational process]. Young Scientist, 22: 203-205.

Shubkin, V.N. (2010). Sociologiya i obshchestvo: Nauchnoe poznanie i etika nauki [Sociology and society: Scientific knowledge and ethics of science]. Monograph. Moscow: Center for Social Forecasting and Marketing. Retrieved from: https://socioline.ru/files/5/39/shubkin v.n. - sociologiya i obshchestvo - 2010.pdf

Slastenin, V.A., Isaev, I.F., Mishchenko, A.I., Shiyanov, E.I. (2000). Pedagogika [Pedagogy]: a textbook for students of pedagogical educational institutions. Moscow: School-Press.

Vinenko, V.G. (1997). Sinergetika v shkole [Synergetics at school]. Pedagogy, 2: 55-60.

Yakusheva, S.D. (2012). "Sinergeticheskij podhod v razvitii professional'nogo masterstva sovremennogo pedagoga [Synergetic approach in the development of professional skills of a contemporary teacher]", In: Proceedings of the 13th International scienceto-practice conference "Personality, family, and society: Issues of pedagogy and psychology". Novosibirsk: Siberian Academic Book. Retrieved from: http://spkurdyumov.ru/education/sinergeticheskij-podxod-v-razvitiiprofessionalnogo-masterstva-sovremennogo-pedagoga/

Zagvyazinsky, V.I. (1995). Metodologiya i metodika social'no-pedagogicheskogo issledovaniya [Methodology and technique of socio-pedagogical research]. Moscow: Association of Social Pedagogues and Social Workers. 
Zagvyazinsky, V.I., Atakhanov, R. (2001). Metodologiya i metody psihologopedagogicheskogo issledovaniya [Methodologies and techniques of psychological and pedagogical research]. Moscow: Academia.

Zakharov, N.N., Simonenko, V.D. (1989). Professional'naya orientaciya shkol'nikov [Professional orientation of school children]. Moscow: Enlightenment. 